\title{
The Author Ransoming the Reader or Vice Versa? The Case of Karen Blixen
}

\author{
IEVA STEPONAVIČIŪTE்
}

\begin{abstract}
The Danish classic Karen Blixen (1885-1962) wrote both in English and Danish and she is better known for the English-reading audience by her pseudonym Isak Dinesen. The article takes its departure from two extremes in her reception. The first extreme is the paramount interest in her person and life, and the other one is the new-critical and post-structural rejection of her biography. The present article pursues the middle way. First of all, this is done by tracing the presence of the fictional construct of the author and the storyteller (however, in many ways related to Karen Blixen's person) in her texts, such as "Babette's Feast”, "The Young Man with the Carnation" and "Deluge at Norderney". Second, the article demonstrates how Blixen's texts sanction the audience's freedom and imply that reception is part of the artistic act. Finally, it suggests that Blixen's readers can return the generosity, which Blixen's $\propto u v r e$ demonstrates in their respect. This can be done by applying biographical material intertextually, when interpreting these stories or staging them in one's mind - without any obligation to treat the writer's person and life as the ultimate and stable source for the meaning of these stories.
\end{abstract}

Keywords: Karen Blixen; Isak Dinesen; reception; 'biographical irreversibility'; the narrator figure; author as a construct; the reader-author relationship; "Babette's Feast"; "The Young Man with the Carnation"

\section{The haunting author}

At a recent literary conference, during an informal conversation, I heard a curious confession: a prominent Danish literary scholar had once, in his student years, made water on Karen Blixen's grave. Interestingly, this act can be related to Blixen's story “The Dreamers” (Seven Gothic Tales, 1934), in which human life is reflected upon in such terms: "what is man, when you come to think upon him, but a minutely set, ingenious machine for turning, with infinite artfulness, the red wine of Shiraz into urine?" (Dinesen 1963: 275). This idea is voiced by the Arab storyteller, Mira Jama, who, by making this unexpected comparison, nevertheless implies that man's life is not futile if it used to perform artistic, amorous, ethical or spiritual acts: "But in the 
meantime, what has been done? A song has been composed, a kiss taken, a slanderer slain, a prophet begotten, a righteous judgment given, a joke made" (ibid.). The act performed at Blixen's grave was, of course, not meant as a tribute to Blixen's provocative art: the person who committed it (and who later became a most insightful expert of this art) had no intention to conceal that it had been a protest against the cult of Blixen's personality. In the 1980s, about the time when Blixen's centenary was celebrated, the interest in her person reached such grotesque dimensions in Denmark that Sven H. Rossel named it 'necrophilia as a literary phenomenon' ("nekrofili som litterært fænomen”, Rossel 1986: 9), while Hans Hertel characterised it as 'Blixen-fetishism' ("Blixen-fetichismen”), which surpassed any parody (Hertel 1996: 228).

Blixen's most recent anniversary was, quite symbolically, fifty years since the author's death, and it was marked by the conference Karen Blixen idet 21. århundrede ('Karen Blixen in the $21^{\text {st }}$ century'), held in Copenhagen on the 5-7th of September 2012. It represented a diversity of approaches to Blixen's œuvre and did not mention much about her personality and life. The younger, post-Aage Henriksen ${ }^{1}$ generation of Blixen scholars seem to find enough in her texts to keep them occupied, and some quite outspokenly ignore the author's biography. The uncritical fascination with Blixen seems also to be gone, and one can name, in this connection, the anthology of articles on Out of Africa (Bøggild \& Engberg 2012), by which Blixen scholars in Denmark and abroad reacted towards the accusations of racism against Blixen and where post-colonial issues were thoroughly analysed.

Nevertheless, at least for a person who is not a permanent resident of Denmark, but who takes an interest in the culture and society of the country, Blixen still appears to be a very conspicuous Danish public figure, and certainly not only because her picture looks at you from older 50 Danish crown bills. The Danish cultural media abounds in messages concerning the author. Blixen has been recently artistically reincarnated as Madam Nielsen one of Nielsen's (earlier - Das Beckwerk, earlier - Claus Beck-Nielsen) ironic hypostases. ${ }^{2}$ Blixen's letters from Africa in four volumes (Juhl et al. 2013), supplied with new material as compared to the earlier editions, have received wide media coverage. The creation of the biopic Tanne about Blixen's preAfrican years has turned into a drama; however, despite first the director, Bille August, and later the scriptwriter Peter Asmussen, leaving the project, its

1 Professor Aage Henriksen (1921-2011), who was, in interesting ways, personally related to Karen Blixen, and had been a dominant (if not the dominant) figure in Blixen-studies for many years.

2 See the artist's website "The Nielsen movement", http://nielsen.re. 
producer Regner Grasten is still hopeful it can premiere one day (Bruun 2015), although it is difficult to raise necessary funds. ${ }^{3}$ The biographies of Blixen's father by Tom Buk-Swienty $(2013,2014)$ seem to have sparked a renewed interest in her family, including the discussion whether the writer had an illegitimate half-sister or not (see, for example, Winther 2015).

The sustainable interest in Blixen's person and life has, of course, the simple explanation that both have been quite extraordinary, and because she, as the commonplace goes, has put much effort in creating a myth about herself. Blixen's seventeen years in Africa were full of dramatic experiences, but also after coming back to Denmark, Blixen often shocked the public with her provocative statements, constant role-playing, extravagant outfits and manners, and even a "spiritual harem" of young poets she liked to surround herself with. Judith Thurman's biography (Thurman 1982) still remains the most exhaustive and most read account of Blixen's life, while Sydney Polack's film Out of Africa (1987), which is largely based on this biography, has spread the knowledge on Blixen's African life widely throughout the world.

The fact that Blixen wrote Out of Africa in 1937 and Shadows on the Grass in 1960, for which her real-life experience in colonial East Africa is an important background, must also play a role in not letting Karen Blixen's person rest in peace. What is perhaps more surprising is that one is also haunted by Blixen's "ghost" when reading her tales and stories. Dag Heede has explained the common overemphasis in Blixen studies on the human being outside her stories by the absence of the human element in the stories (Heede 2001: 23), but it may also have to do with the fact that we find in them her person inscribed as a fictional construct.

\section{"By thy mask I shall know thee": storytellers with Blixen's face}

Sometimes, as, for example, in "Babette's Feast" (Anecdotes of Destiny, 1958), we see the real author's image peep out from behind the back of the, at first sight, quite covert, heterodiegetic narrator, especially if one reads the English and the Danish versions against each other. The only obvious self-reference is the deictic "[s]ixty-five years ago" (Dinesen 1986a: 23) / "[f]or femogtres Aar siden" (Blixen 1958: 31), by which the narrator locates herself with respect to the time of the central event of the story, the feast. We can, however, determine the time of narration by making some basic calculations: we know that, in the

3 Grasten claims that this difficulty arises, because his ambition is to produce a nonmainstream film, see Ritzau 2016. 
English text, the feast takes place twelve years after Babette's arrival, which occurs in 1871 (Dinesen 1986a: 24, 32, 35). Thus, the time of narration must be $1948(1871+12+65)$. This is about the time when the story was written (it was first published in Ladies' Home Journal in 1950). It is curious that in both Danish versions (the translation by Jørgen Claudi published in 1952, and the one composed by Blixen herself and published in Skcebne-Anekdoter in 1958), fourteen, not twelve years separate Babette's arrival and the feast (Dinesen 1952: 7, 18, 22; Blixen 1958: 32, 40, 42). This not only suggests, that Blixen might have been actively involved in the first translation, but it also moves the time of the feast to 1885, the year Blixen was born, and the time of narration to 1950. The two years that expand the duration of Babette's stay with the sisters before the dinner in the Danish texts correspond exactly to the two-year interval that separates the first English and Danish publications. This extra-textual information changes our perception of the narrator. The narrator, who shares biographical details with the author, who gets older as she moves from the English to the Danish text, can no longer be considered an anonymous narrative agency, but becomes a full-fledged character - with a face reminiscent of the author's own. We read about Babette, who, like a real cultural hero, creates her cosmos out of opposing elements and becomes an instrument of fate, granting people back what they have once rejected. However, as I have argued elsewhere (Steponaviciute 2011: 160-165), if we have the earlier mentioned parallel in mind, we become much more aware that this is also a story about a professional storyteller, who, through Babette's miracle, metaphorically reflects on the nature of art both she, a fictitious person, and the real author practice.

In many of Blixen's tales, we encounter practitioners of literary art in a much more tangible form - as explicit characters. Most are oral storytellers, such as the already mentioned Mira Jama ("The Dreamers", Seven Gothic Tales and "The Diver", Anecdotes of Destiny), Miss Malin Nat-og-Dag from "Deluge at Norderney" (Seven Gothic Tales), the old woman from "The Blank Page" or Cardinal Salviati from "The Cardinal's First Tale” and "The Cardinal's Third Tale" (all three in Last Tales 1957). In theory, you do not need to know anything about Blixen's person in order to realise that these characters, who advocate the poetics of silence and masquerade, and who scorn the all-toohuman realism of the modern novel, are emblems of Blixen's own art. Here, it would suffice with the notion of the career author, the term proposed by Wayne Booth and modified by Seymor Chatman to denote "the subset of features shared by all the implied authors (that is all individual intents) of the narrative texts bearing the name of the same real author" (Chatman 1993: 88). However, if one has seen Blixen's interviews given during her trip 
to the USA (as, for example, featured in the documentary by Marcus Mandal and Anna von Lowzow, Karen Blixen: Out of This World, 2005), listened to her radio orations or seen her pictures taken not long before her death (as, for example, those included in Lasson and Selborn 1992), one will be likely to project her manner of speaking, her gestures, and even more onto her storytelling characters, when idiosyncratically "staging" the text in one's mind - a tendency, which Jon Helt Haarder calls 'biographical irreversibility' ("biografisk irreversibilitet", Haarder 2014: 19, 26). This especially applies to Blixen's certain female characters, especially the carnivalistically grotesque Miss Malin Nat-og-Dag in “The Deluge at Norderney”. Physically a sterile old wreck, "looking like a corpse of 24 hours" (Dinesen 1963: 167) and "a scarecrow in a field" (ibid. 130), whose head is a reminder of "that death's head by which druggists label their poison bottles" (ibid. 187), yet pregnant with stories, she paradoxically adumbrates Blixen's own appearance many years after the tale was published. Whether it was Blixen, God or Satan who inscribed this into the text, the connection is unmistakable. It can only be testified by Margaret Atwood's words, in which she describes how she first saw a photograph of Karen Blixen (Isak Dinsen):

To my young eyes, this person in the pictures was like a magical creature from a fairytale: an impossibly aged woman, a thousand years old at least. Her outfits were striking and the makeup of the era had been carefully applied, but the effect was carnivalesque - like a dressed-up Mexican skeleton. Her expression, however, was bright-eyed and ironic: she seemed to be enjoying the show-stopping, if not grotesque, impression she was making. (Atwood 2013)

What also connects Blixen and her storytellers is the authority that they demand for themselves by being able to produce a story. Not any kind of story, but one that alone can "answer that cry of heart [...] 'Who am I?"' (Dinesen 1986b: 26); the truth of which has nothing to do with the truth of realism, which, as we are told, is "only for tailors and shoemakers" (Dinesen 1963: 141). Indeed, the image of Blixen as a high brow, aristocratic or even snobbish author is deeply rooted in the common reception of her authorship and person (see, for example, Egholm Andersen 2004: 65). You would not be surprised to meet a Dane who, for that reason, outright rejects reading her texts, although it may sound paradoxical with regard to what has been said earlier in this paper about her popularity.

Nevertheless, Blixen's tales exhibit a strong social aspect, at least in one respect. Her storytellers (as if testifying to Benjamin Walter's theory that storytelling is social by nature and, therefore, cardinally different from the 
art of the novel (Benjamin 2002: 156)) are always positioned vis-à-vis their audience, and the audience is, by different means, encouraged to take an active part in the artistic process. The modern reader may be surprised by the metafictional insights contained within Blixen's texts, some of which correlate directly with the classical postulates of reception theory to be formulated years later. The image of "The Blank Page" in the eponymous tale, a framed piece of bridal sheet that is "snow white from corner to corner" (Dinesen 1986b: 104) is used to represent the oxymoronic idea of "the silence that speaks" and seems to be a fitting parallel to Wolfgang Iser's theory of 'blanks' or 'gaps' ("Leerstellen") to be filled in by the individual reader in his or her own idiosyncratic manner (Iser 1972: 68). The picture, which, by contrast to other pictures in the gallery, disrupts the beholder's natural expectations and demands to construct the plot behind it, is also reminiscent of the distinction between 'readely' ("lisible") and 'writerly' ("scriptible") texts introduced by Roland Barthes (1970: 10-12).

The earlier mentioned Miss Malin explicitly declares reception to be part of the creative act, when she, through the typical-for-Blixen double coding of discourse, blends the rhetoric of sexuality and aesthetics: "Where, my lord is music bred - upon the instrument or within the ear that listens? The loveliness of woman is created in the eye of man" (Dinesen 1963: 159).

The text in which the dialectic relation between the author and the audience is most explicitly discussed is "A Consolatory Tale" from Winter's Tales (1942). Its protagonist, Charlie Despard, is a professional writer, whose creative evolution from heavy realism towards a more symbolic art, we followed in an earlier tale of the same collection - "The Young Man with the Carnation". Charlie is tormented by the realisation of his total dependence on his reader:

$[\mathrm{T}]$ he relation of the artist to the public $[. .$.$] is as terrible as marriage [\ldots][\mathrm{W}] \mathrm{e}$ are, the artist and the public, much against our own will, dependent upon one another for our very existence". [...] Where there is no work of art to look at, or to listen to, there can be no public [...] And as to the work of art $[\ldots]$ does a painting exist at which no one looks? - does a book exist which is never read? [...]. (Dinesen 1983: 203)

Charlie is, however, consoled by his companion with a telling name, Aeneas Snell, who tells a story about the complicated relationship between Prince Nasrudin, who walks the streets of Teheran disguised as a beggar, and a real beggar, whom everyone believes to be a disguised Nasrudin. Eventually, the prince gives up his role, putting an end to the confusion of who is copying whom. Charlie learns from Aeneas that the author-public dichotomy is just 
another pair of opposites, such as death and life, man and woman or the poor and the rich, which, only taken together, make the world complete, or in the beggar's words, "are two locked caskets, of which each contains the key to the other" (Dinesen 1983: 212, 216, 218).

In her astute analysis of the tale, Susan Brantly concludes: "opposites form a unity, but remain distinct. [...] the prince remains a prince and the beggar remains a beggar" (Brantly 2002: 142). However, through Aeneas's story and Charlies's reaction to it, Blixen is also pointing towards the possibility of stepping out of one role and into the other, as Charlie, a moment ago, functioned as a listener, now is ready to perform his own creative act: "Yes, a good tale, $[\ldots]$. No, $[. .$.$] not very good, really, you know. But it has moments in$ it that might be worked up, and from which one might construct a fine tale" (Dinesen 1983: 218).

Charlie seems to have found an answer to his earlier question: what good art is to man. Art has value, Blixen's tale suggests, as long as it produces an imaginative response, as long as it can turn the audience into storytellers and vice versa. It is hardly accidental that "A Consolatory Tale" is the concluding story of Winter's Tales, and the collection ends with Charlie's words quoted a moment ago. Charlie seems to have finally realised what God (in the manner of The Book of Job) demanded from him in the earlier tale. There Charlie finds himself, by mere chance, in bed with a girl who happens to be the lover of the mysterious young man with the carnation. He leaves immediately after having realised his mistake and later congratulates himself with not taking what belongs to this man his "brother" (ibid. 35), who apparently is a symbolic messenger of different artistic sensibility. It seems, however, that this is exactly what God blamed him for: "I gave you all that last night [...] it was you who jumped out of bed to go to the end of the world from it" (ibid. 33). To take what belongs to another and make it your own, in hopes that what is yours will also be one day appropriated by others - this seems to be the message of Blixen's poetics. Harold Bloom could have used her texts to support his idea that literature canonises itself through strong authors who subsume the tradition by creatively misreading it and later are subsumed by others (Bloom 1994: 28).

\section{Obliging generosity}

Blixen's entire $\propto u v r e$ demonstrates this artistic ethos, and its intensive and playful intertextuality, combined with open-ended and polyphonic narrative structures, already encourages the reader's active involvement. However, when you, as a reader, see that the processes of reception, including the evolution 
of reception into new creation, are being reflected upon and even staged in Blixen's texts, you can read this as a renouncement of the patent of final truth and an inscribed invitation for you to practice your own creativity with respect to the text. This mandate to engage in the text's creation calls for the same generosity on the reader's part. There is a passage from Blixen's early text written in the 1920s, the essay "Moderne Ægteskab og andre Betragtninger”, in which she develops her theory of love as play, but it is also a theory of play in a much broader sense - after Schiller, but before Huizinga (for more on that, see Steponavičiūte 2011: 71-82). The present paper is not about that; however, the words that will be quoted here remind us that no fair play, no fair communication is possible without the mutual gallantry of all participants:

Det fordres ikke lidt af den, som virkelig skal kunne lege. Mod og fantasi, humor og intelligens, ... men især den blanding af uselviskhed, generrøsitet, selvbeherskelse og ynde, som kaldes ,„gentilezza”. (Blixen 1992: 45)

Much is demanded of those who are to be really proficient at play. Courage and imagination, humor and intelligence, but in particular that blend of unselfishness, generosity, self-control and courtesy that is called gentilezza. (Dinesen 1986c: 83)

Coming back to where I started - whether we should disregard the real author in our engagement with her legacy - I would answer that this is unnecessary. In Blixen's case, one can approach the author in good consciousness, even if working with the post-structural idea of the text. The image she created as a person and left to us rests on similar principles to those that dominate her literary production (the attempt to stir people's imagination and the ability to surprise and provoke the addressee), which certainly had an effect on how many readers have received her texts. Therefore, the recorded instances of Blixen's public and private behaviour, as well as her personal enunciations, should not be rejected, but can be treated as an integral part of her creative enterprise; not as the source of stable and final meaning, of course, but as texts (intertexts, if you like) that can help our imagination approach her tales.

4 The text was given the present title when it was first published after the author's death in Blixeniana 1977. It was translated into English by Anne Born and published in Dinesen 1986c. 
The Author Ransoming the Reader or Vice Versa?

\author{
Ieva Steponavičiūtè \\ ieva.steponaviciute@flf.vu.lt \\ Skandinavistikos centras \\ Vilniaus universitetas \\ Universiteto g. 5 \\ LT-01513 Vilnius \\ LIETUVA / LITHUANIA
}

\title{
References
}

Atwood, M. 2013. Margaret Atwood on the show-stopping Isak Dinesen. - The Guardian, 29.11, http://www.theguardian.com/books/2013/nov/29/margaretatwood-isak-dinesen (15.05.2016).

Barthes, R. 1970. S / Z. Paris: Seuil.

Benjamin, W. 2002. The Storyteller. Observation on the Work of Nikolaj Leskov. W. Benjamin, Selected Writings, Volume 3: 1935-1938. Cambridge, Mass.: Harvard University Press, 143-166. [Originally published as “Der Erzähler. Betrachtungen zum Werk Nikolai Lesskows” in Orient und Okzident (1936).]

Blixen, K. 1958. Skcebne-anekdoter. København: Gyldendal.

Blixen, K. 1992. Moderne ægteskab og andre betragtninger. - K. Blixen, Samlede essays. København: Gyldendals Tranebøger, 7-55.

Bloom, H. 1994. The Western Canon: The Books and School of the Ages. New York: Harcourt Brace \& Company.

Brantly, S. C. 2002. Understanding Isak Dinesen. Columbia: University of South Carolina Press.

Bruun, N. 2015. Regner Grastens drømmeprojekt udsættes igen. - Filmmagasinet Ekko, 27.02, http://www.ekkofilm.dk/artikler/regner-grastens-drommeprojektudsaettes-igen/ (15.05.2016).

Buk-Swienty, T. 2013. Kaptajn Dinesen: Ild og blod. København: Gyldendal.

Buk-Swienty, T. 2014. Kaptajn Dinesen: Til døden os skiller. København: Gyldendal.

Bøggild, J., Engberg, C., eds. 2012. Jeg havde en farm i Afrika. Estetik og kulturmøde $i$ Karens Blixens Den afrikanske Farm. Hellerup: Forlaget Spring.

Chatman, S. 1993. Coming to Terms. The Rhetoric of Narration in Fiction and Film. Ithaca/London: Cornell University Press.

Dinesen, I. 1952. Babettes gestebud. Oversat af Jørgen Claudi. København: Forlaget Fremad.

Dinesen, I. [Karen Blixen]. 1963. Seven Gothic Tales. Harmondsworth: Penguin Books.

Dinesen, I. [Karen Blixen]. 1983. Winter's Tales. Harmondsworth: Penguin Books.

Dinesen, I. [Karen Blixen]. 1986a. Anecdotes of Destiny. Harmondsworth: Penguin Books.

Dinesen, I. [Karen Blixen]. 1986b. Last Tales. Harmondsworth: Penguin Books. 
STEPONAVIČIŪTĖ

Dinesen, I. [Karen Blixen]. 1986c. On Modern Marriage and Other Observations, trans. by Anne Born. New York: St. Martin's Press.

Egholm Andersen, F. 2004. Karen Blixen som ung. Frederiksberg: Her \& Nu.

Haarder, J. H. 2014. Performativ biografisme. København: Gyldendal.

Heede, D. 2001. Det umenneskelige: Analyser af seksualitet, køn og identitet hos Karen Blixen. Odense: Odense Universitetsforlag.

Hertel, H. 1996. Karen Blixen superstar. - H. Hertel, Karen Blixen superstar: glimt af det litercere liv $i$ medialderen. København: Nørhaven og Forening for boghaandværk, 228-231.

Iser, W. 1972. Der implizite Leser. Kommunikationsformen des Romans von Bunyan bis Beckett. München: Wilhelm Fink Verlag.

Juhl, M. et al., eds. 2013. Karen Blixen i Afrika, en brevsamling, 1914-31, 4 bind. København: Gyldendal.

Lasson, F., Selborn, C., eds. 1992. Karen Blixen. En digterskabne i billeder. Rungstedelund: Karen Blixen Museet.

Ritzau. 2016. Regner Grasten: Middelmådighed dominerer dansk film. Information, 07.03,

https://www.information.dk/telegram/2016/03/regner-grasten-middelmaadigheddominerer-dansk-film (15.05.2016).

Rossel, S. H. 1986. Hun har faktisk også skrevet bøger. Betragtninger over nekrofili som litterært fænomen: Karen Blixen 1885-1962. - Nordica, 3, 9-21.

Steponavičiūtè, I. 2011. Texts at Play: The Ludic Aspect of Karen Blixen's Writings. Vilnius: Vilnius University.

Thurman, J. 1982. Isak Dinesen: The Life of a Storyteller. New York: St Martin's Press.

Winther, T. M. 2015. Ukendt lillesøster kaster nyt lys over Karen Blixen. - Politiken, 21.03, http://politiken.dk/kultur/boger/ECE2597957/ukendt-lillesoester-kasternyt-lys-over-karen-blixen/ (15.05.2016). 